\title{
Article \\ Mechanical Properties of Historic Masonry Stones Obtained by In Situ Non-Destructive Tests on the St. Agostino Church in Amatrice (Italy)
}

\author{
Alessandro Grazzini * (D) and Giuseppe Lacidogna (D) \\ Department of Structural Geotechnical and Building Engineering, Politecnico di Torino, 10129 Turin, Italy; \\ giuseppe.lacidogna@polito.it \\ * Correspondence: alessandro.grazzini@polito.it
}

check for updates

Citation: Grazzini, A.; Lacidogna, G. Mechanical Properties of Historic Masonry Stones Obtained by In Situ Non-Destructive Tests on the St. Agostino Church in Amatrice (Italy). Appl. Sci. 2021, 11, 6352. https:// doi.org/10.3390/app11146352

Academic Editor: Victor Giurgiutiu

Received: 11 June 2021

Accepted: 7 July 2021

Published: 9 July 2021

Publisher's Note: MDPI stays neutral with regard to jurisdictional claims in published maps and institutional affiliations.

Copyright: (c) 2021 by the authors. Licensee MDPI, Basel, Switzerland. This article is an open access article distributed under the terms and conditions of the Creative Commons Attribution (CC BY) license (https:/ / creativecommons.org/licenses/by/ $4.0 /)$.
Featured Application: The use of non-destructive diagnostic techniques for the in situ and noninvasive mechanical characterization of historic stone masonry.

Abstract: The design of strengthening and securing work for historic buildings requires knowledge of the masonry mechanical characteristics, often obtainable through laboratory tests that require invasive samples. The non-destructive techniques, applicable in situ in a rapid and non-invasive way, represent a valid alternative to estimate mechanical strengths without destructive sampling. In this study, a methodology was calibrated which, by combining the results of the ultrasonic and impact tests, makes it possible to reach a good estimate of the compression strength and elastic modulus of a particular rock: sandstone. Most buildings in Amatrice, the city devastated by the violent earthquake of Central Italy in 2016, were built by means of this sedimentary rock. By carrying out a diagnostic campaign on the remaining walls of the St. Agostino church in Amatrice, it was possible to obtain a correlation, specific for this case study, between the compression strengths from laboratory tests and the results of the ultrasonic and impact tests. Unlike the traditional Sonreb methods, this methodology wanted to favor the use of the impact method instead of the sclerometrer test. In this way, it will be possible to operate on other damaged buildings of similar construction types located in the seismic crater of Amatrice, evaluating the mechanical characteristics of the masonry structures be means of in situ non-destructive tests in order to design the safety and strengthening work.

Keywords: historic building; masonry stone; Amatrice earthquake; structural safety; non-destructive techniques (NDT); ultrasonic test; impact test

\section{Introduction}

Historic buildings located within seismic areas suffer significant damage and collapse whenever earthquakes of considerable intensity highlight their structural vulnerabilities. The ancient masonry structures are affected by material degradation, high variability in the quality of the masonry texture, an absence of effective connections between walls and floors, an absence of sufficiently rigid floors, and a lack of adequate box behaviour [1-4]. Many of these damaged buildings had never received a careful analysis of seismic vulnerabilities and adequate seismic improvement interventions [5,6]. In particular, churches are seismically vulnerable buildings due to the presence of very high naves without intermediate constraints on the walls, as well as being subject to other common structural problems linked to poor masonry quality $[7,8]$.

The 2016 Central Italy earthquake, which caused the total destruction of Amatrice and many other historic villages around it, highlighted the vulnerability of historic buildings due to decay, an absence of anti-seismic devices and poor maintenance in the masonry structures. The buildings of Amatrice were characterized by sandstone and marl stones of low strength, but, above all, poor in calcium carbonate. Since the production of lime 
took place with stones quarried in the same sites from which the building stones were obtained, they were capable of giving only "poor" lime. From this lime, a mortar, as the binder of the masonry, was obtained with low calcium content, which over time degraded more rapidly, no longer binding the stones of the masonry. In particular, one of the symbolic damaged buildings in the historic center of Amatrice was the St. Agostino church, a Romanesque-Gothic construction built in 1428 (Figure 1a), which suffered an almost total collapse that occurred in progressive phases during the long seismic earthquake swarm after the first violent earthquake of 24 August 2016 (Figure 1b) [9]. The façade was composed of sandstone, and the interior was made from a single nave with a wooden roof and exposed trusses.

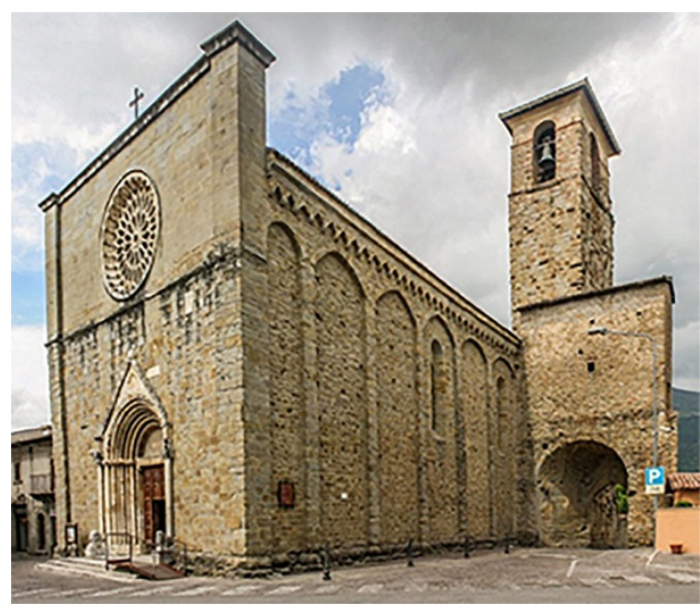

(a)

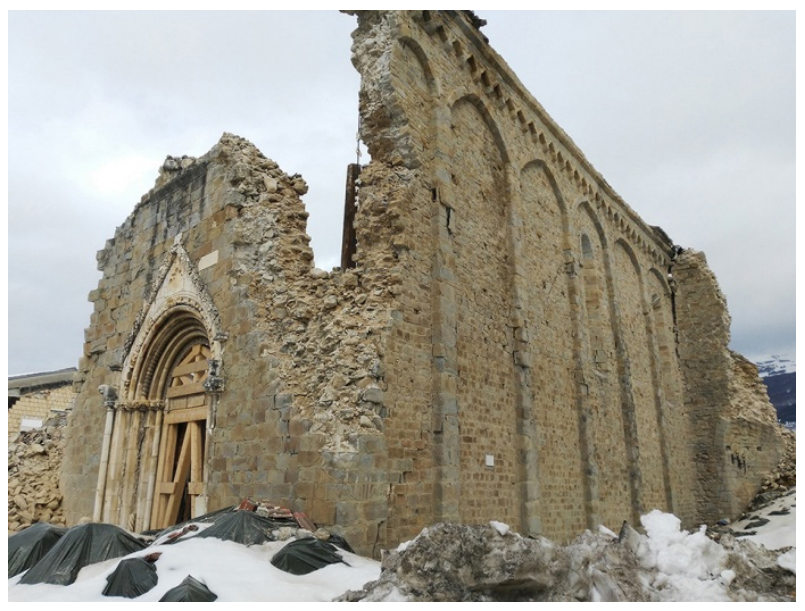

(b)

Figure 1. St. Agostino church in Amatrice before (a) and after (b) the seismic earthquake swarm of 2016 in Central Italy.

The safeguarding of this immense artistic heritage urgently deserves careful knowledge of the walls' mechanical characteristics in order to better design strengthening work (compatible with the monumental buildings) and prepare more accurate computational models with different levels of complexities, as described in [10-14], among others. In the field of cultural heritage, non-invasive diagnostic techniques offer a considerable contribution to the knowledge of the structural criticalities of historic buildings, partly replacing the most destructive tests that are not compatible with the conservation of the architectural aspects of the historic building [15-18]. Non-destructive tests (NDT) are the set of tests and surveys conducted using methods that do not alter the material and do not require the destruction or removal of samples from the structure, aimed at searching for and identifying defects in the structure itself.

The determination of the mechanical strength of the historic masonry structures and their components (stones, bricks and mortar) is a very important issue for the evaluation of the static and seismic safety of the existing building, especially in consideration of any damage already suffered. Often, this determination takes place through semi-destructive tests, such as flat jacks, or through the extraction of samples to be tested in the laboratory. However, in the context of monumental buildings, the destructive diagnostic techniques must be limited, and can be accompanied (in many cases, partially replaced) by nondestructive techniques, which for historical masonry concern precisely the sonic and ultrasonic technique, and the impact test [19].

One of the non-destructive methods calibrated for evaluating the compression strengths of concrete is the Sonreb method. It is based on calibration curves, obtained from several experimental tests, which correlate the compression strength of the concrete with the ultrasonic speed waves and with the rebound values of the sclerometer, so that only one or both non-destructive techniques can be used in situ to estimate the strength of the reinforced concrete structure without invasive laboratory tests. Unlike the traditional Sonreb method 
for concrete structures, several authors, such as Vasconcelos et al. [20], Vasanelli et al. [21], Cobanoglu et al. [22] and Concu at al. [23], also calibrated and validated the application on stone structures. The calibration on stones requires different curves in relation to the different types of lithotypes. The precision of these calibration curves varies according to the anisotropy that characterizes the different lithotypes.

This experimental research has positively evaluated the application of the Sonreb method on a specific case study for the estimation of the mechanical characteristics of stone walls damaged by the earthquake: the St. Agostino church in Amatrice. The purpose was to correlate the compression tests carried out in laboratory on the stones taken from the masonry ruins of the church, with the ultrasonic and impact tests performed in situ on the same stones. In fact, unlike the traditional Sonreb methods, this methodology wanted to favor the use of the impact method instead of the sclerometer test, as it is a similar tool that nevertheless offers much more information. The sclerometer test records only the returned elastic energy. On the other hand, the impact test also records the given energy, the dissipated energy, the impact time, and the maximum force, as well as being able to estimate and the elastic modulus of the material [19].

The correlation curves obtained in this experimental research can be used for further diagnostic investigations on other masonry buildings and historic monuments in the Amatrice area, built with the same masonry texture (Figure 2). It will be sufficient to calibrate the curves with reference to limited core samples or other semi-destructive tests, and then estimate in situ the mechanical strengths by mainly performing non-destructive tests for the benefit of the conservation of architectural artefacts. As a matter of fact, in Section 11.10 .3 of the Italian technical codes for construction [24], insofar as this approach is to be considered mainly applicable for dimensioned square stones, the legislation provides for the possibility of estimating the compression strength of masonry by comparing the strength of the individual materials, stone blocks and mortar. The compression strength of the mortar can be estimated in situ by means of a Windsor penetrometric test or by means of small samples and the packing, in the laboratory, of specimens of similar composition tested by compression [25]. In this way, both the design of urgent safety work and postearthquake strengthening work will be able to make use of the mechanical strength values of the old stones and of the masonry textures formed with them, derived mainly through non-invasive tests. The mechanical strength values of the individual stones will be useful for the subsequent estimation of the compression strength of masonry structures.

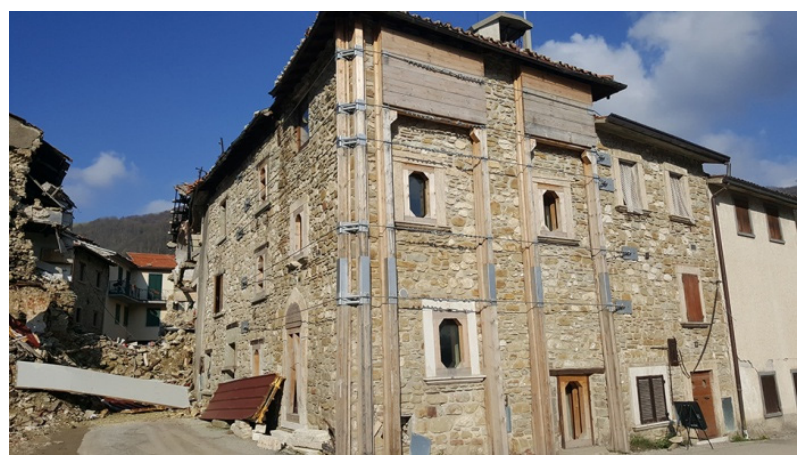

(a)

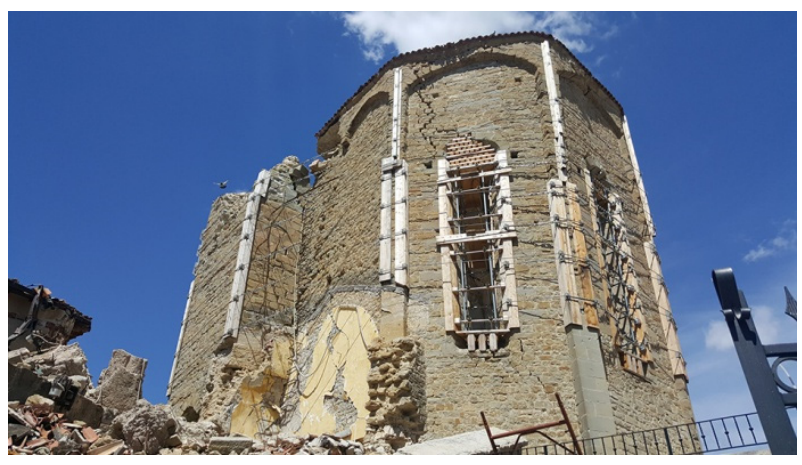

(b)

Figure 2. (a) Damaged masonry buildings in the area around the epicenter of the 2016 Central Italy earthquake; (b) St. Francesco church in Amatrice, damaged by the same earthquake.

\section{Materials and Methods}

The experimental tests consisted of:

- Compression tests on cores obtained by extraction from masonry stones taken in situ after the collapse of the St. Agostino church (Figure 3a); 
- Ultrasonic tests for the determination of the elastic dynamic modulus performed on the same stones (Figure 4);

- Impact tests carried out on the same stones (Figure 5).

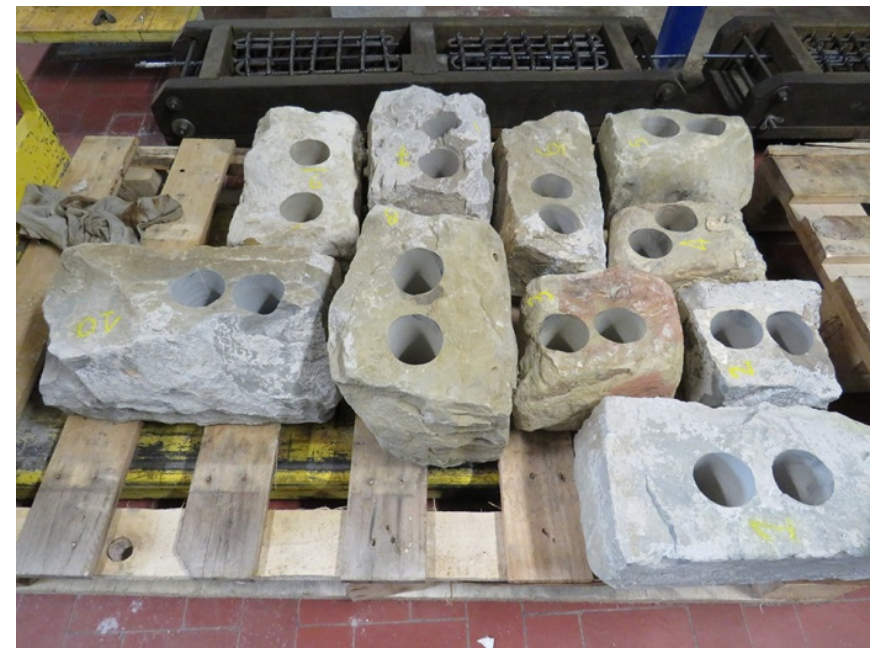

(a)

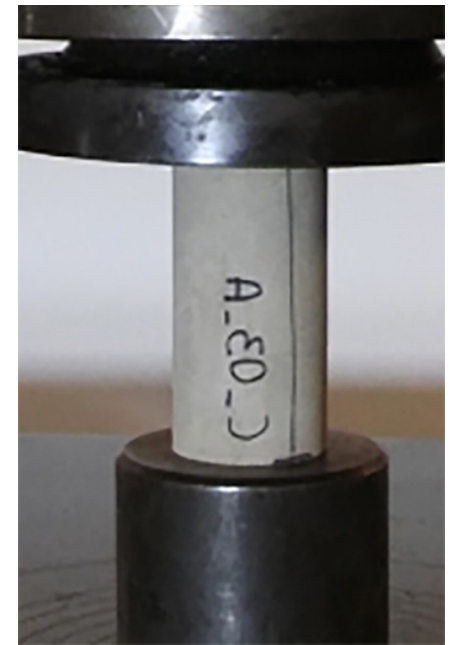

(b)

Figure 3. (a) Extraction of cores from stones; (b) compression test on the stone core sample.

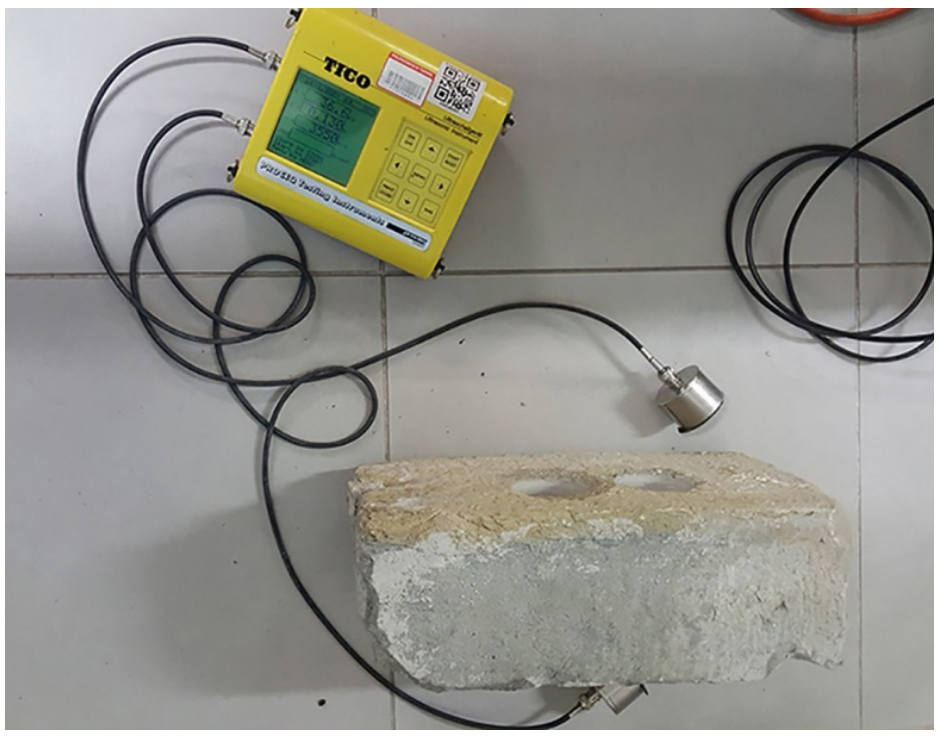

Figure 4. Ultrasonic test setup. 


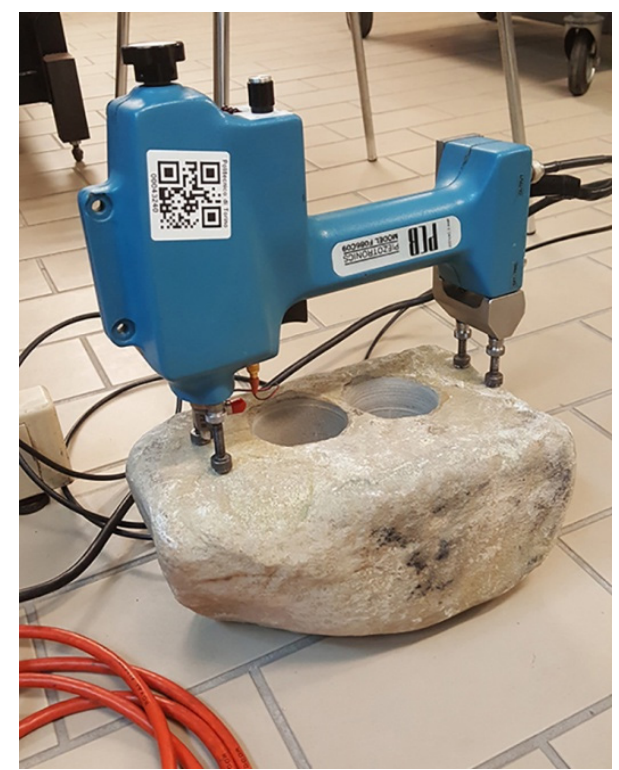

(a)

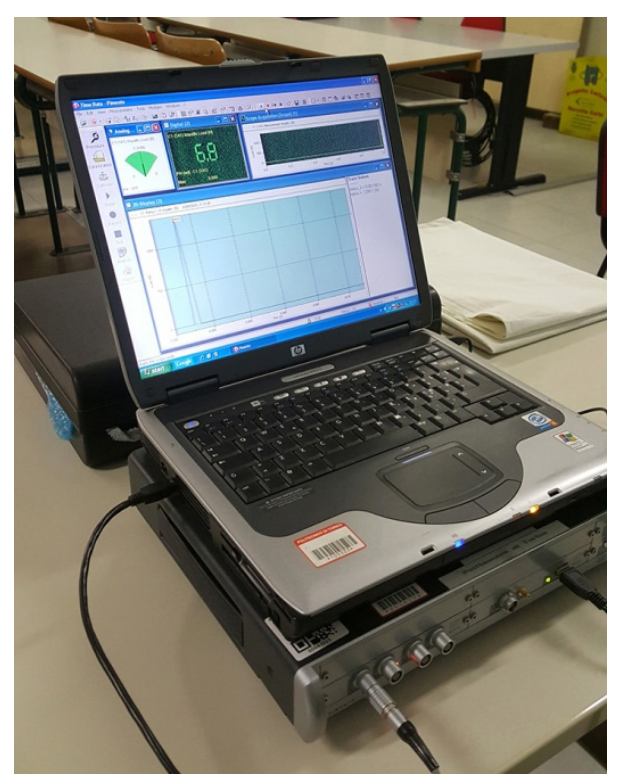

(b)

Figure 5. (a) Electric impact hammer; (b) Pimento model multichannel LMS signal analyzer.

\subsection{Compression Test}

For the assessment of the stone mechanical characteristics and the wall texture of the St. Agostino church, 10 stone samples were taken in situ from the rubble that resulted from the collapse. For each stone, 2 cylindrical specimens were obtained with a diameter of $50 \mathrm{~mm}$ and height of $100 \mathrm{~mm}$ (Figure 3a). The top and bottom surfaces of the cylindrical specimens were mechanically rectified to make them coplanar to the test machine plates, and they were arranged between the press platens without the interposition of friction-reducer layers. The compression tests were carried out using a Baldwin-Zwick $500 \mathrm{kN}$ material testing machine, in accordance with the Italian technical code UNI EN 1926: 2007 [26], by applying a monotonically increasing axial load (force control $1 \mathrm{MPa} / \mathrm{s}$ ) until failure (Figure 3b).

\subsection{Ultrasonic Test}

Ultrasonic tests were also conducted on the same stones to estimate the dynamic elastic modulus $\left(E_{d}\right)$. Ultrasonic inspection is a non-destructive method, in which high frequency sound waves are introduced into the material to be examined, in order to highlight any surface or internal defects. Longitudinal waves were produced by means of an electroacoustic transducer (emitting probe in piezoelectric or magnetostrictive material) placed in contact with the stone surface under test; after passing through a path of known length, the train of waves was converted by a second transducer (receiving probe) into an electrical signal processed by electronic timing circuits that allow measurement of the transit time of the impulses. The ultrasonic test device consisted of: a Proceq Tico ${ }^{\circledR}$ pulse generator; two transducers of $54 \mathrm{kHz}$ (one emitting and the other receiving); a pulse amplifier; and an electronic device for measuring the time interval (Figure 4 ). The speed of the wave $(v)$ depends on the presence of any defects inside the material, and is related to the value of the dynamic elastic modulus $\left(E_{d}\right)$ through the density $(\rho)$ and the Poisson's ratio $(v)$ of the material. Therefore, the value of the dynamic elastic modulus $\left(E_{d}\right)$ of the stone can be obtained using the following relationship, in accordance with the technical standards ASTM D2845 1995 and UNI EN 12504-4: 2005 [27,28]:

$$
E_{d}=v^{2} \rho \frac{(1+v)(1-2 v)}{(1-v)}
$$


In this case, from scientific literature sources $[29,30]$ a $v$ value equal to 0.20 was considered for the sandstone. Three speed measurements were made for each sample.

\subsection{Impact Test}

The impact test represents another valid non-destructive diagnostic technique, capable of evaluating surface detachment phenomena (for example of historical plasters [31]) and of quantifying the static elastic modulus of a material [32]. The methodology is adaptable to any masonry surface, and has already been tested on historic stone structures [33]. The electric impact hammer was a piezotronic $\mathrm{PCB}$, and the impact was performed on the surface material under investigation by a $10 \mathrm{~mm}$ diameter steel ball with a total mass of $207 \mathrm{~g}$, connected to a piezoelectric pulse transducer (Figure 5). For technical and theoretical details related to the use of the instrumentation, please refer to the research previously carried out by the authors in [19,31-33]. The analysis of the diagram $(F, t)$ made it possible to obtain the value of the homogeneous material's elastic modulus $\left(E_{s}\right)$ through the Hertz's impact theory $[34,35]$, using the following equations:

$$
E_{s}=\frac{E^{*} E_{0}\left(1-v^{2}\right)}{E_{0}+E^{*}\left(v_{0}^{2}-1\right)},
$$

where $E^{*}$ was obtained by:

$$
E^{*}=\sqrt{\left(\frac{2.87}{T}\right)^{5} \frac{m^{3}}{R A_{1}}} .
$$

The parameters in Equations (2) and (3) were the following: $A_{1}$ was the area beneath the diagram $(F, t)$ corresponding to supplied energy (see Figure 6), $T$ represented the time in which the contact occurs between the two surfaces; $R$ was the radius of curvature $(10 \mathrm{~mm})$ of the impact mass $m(0.207 \mathrm{Kg}), E_{0}$ was the mass elastic modulus $(222,000 \mathrm{MPa})$, and $v_{0}$ was its Poisson's ratio (0.2), while, with regard to the stone material, a Poisson's ratio of 0.2 was considered $[29,30]$.

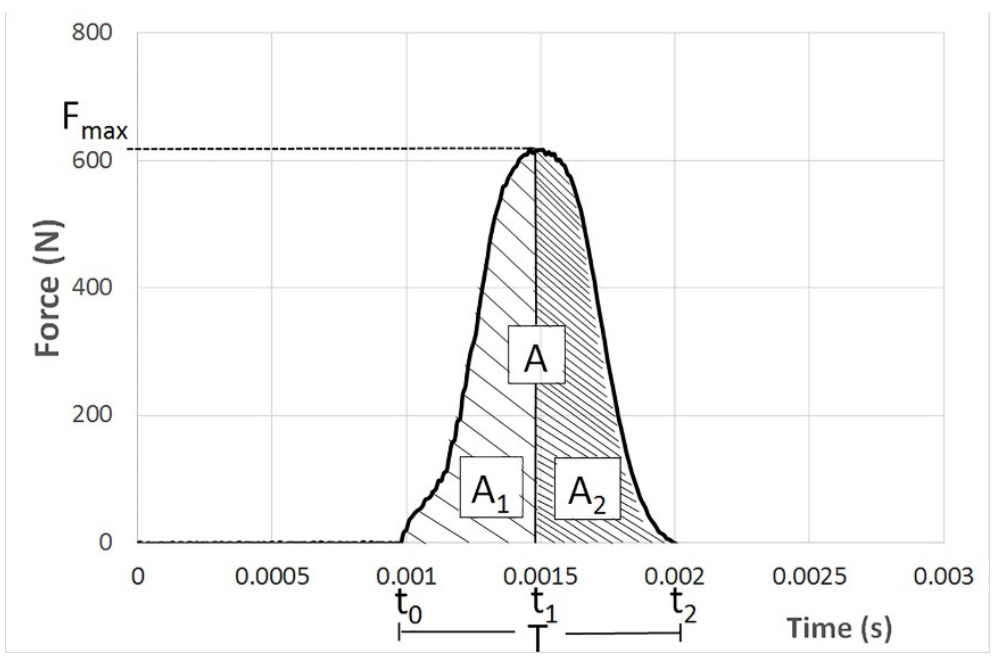

Figure 6. Example of force-time diagram in impact test.

The ratio between the energy returned $\left(A_{2}\right)$ and the energy supplied $\left(A_{1}\right)$ represented the restitution coefficient (e). When it was equal to 1 , the impact was perfectly elastic without dissipated energy. For each stone specimen, 15 impacts $(n)$ were performed to allow stabilization of the restitution coefficient $(e)$ towards unity. 


\section{Results}

The results were related to the tests of 20 samples (cores), obtained from 10 sandstone stones taken from the ruins of the St. Agostino church in Amatrice. The cores were named by the letter $C$, followed by the number of the stone from which they were extracted, and by the letter $\mathrm{A}$ and $\mathrm{B}$, which indicated the first and second extraction. Table 1 summarized the experimental results, comparing the cylindrical compression strength $\left(f_{c}\right)$ with the different values of the elastic modulus: static modulus $\left(E_{s}\right)$ by the secant line of the $f_{c}-\varepsilon$ diagram during the compression test and by impact tests; and speed waves $(v)$ and dynamic modulus $\left(E_{d}\right)$ obtained by ultrasonic tests.

Table 1. Results of laboratory tests correlated to non-destructive tests.

\begin{tabular}{|c|c|c|c|c|c|c|c|}
\hline \multirow{4}{*}{$\begin{array}{c}\text { Specimen } \\
\text { C_01_A } \\
\text { C_01_B }\end{array}$} & \multicolumn{4}{|c|}{ Compression Test } & \multirow{4}{*}{$\begin{array}{c}\begin{array}{c}\text { Impact } \\
\text { Test }\end{array} \\
E_{s} \text { (Mpa) } \\
27,605\end{array}$} & \multicolumn{2}{|c|}{ Ultrasonic Test } \\
\hline & \multicolumn{2}{|c|}{$f_{c}(\mathrm{MPa})$} & \multicolumn{2}{|c|}{$E_{s}$ (Mpa) } & & $E_{d}(\mathrm{MPa})$ & $v(\mathrm{~m} / \mathrm{s})$ \\
\hline & 65.2 & \multirow{2}{*}{75.45} & 23,866 & \multirow{2}{*}{25,624} & & \multirow{2}{*}{28,850} & \multirow{2}{*}{3542} \\
\hline & 85.7 & & 27,382 & & & & \\
\hline C_02_A & 146.5 & \multirow{2}{*}{147.90} & 35,083 & \multirow{2}{*}{36,435} & \multirow{2}{*}{41,722} & \multirow{2}{*}{45,140} & \multirow{2}{*}{4367} \\
\hline C_02_B & 149.3 & & 37,787 & & & & \\
\hline C_03_A & 106.7 & \multirow{2}{*}{87.05} & 32,096 & \multirow{2}{*}{27,760} & \multirow{2}{*}{27,498} & \multirow{2}{*}{25,831} & \multirow{2}{*}{3343} \\
\hline C_03_B & 67.4 & & 23,425 & & & & \\
\hline C_04_A & 150.2 & \multirow{2}{*}{167.60} & 35,670 & \multirow{2}{*}{35,616} & \multirow{2}{*}{33,124} & \multirow{2}{*}{44,859} & \multirow{2}{*}{4370} \\
\hline C_04_B & 185.0 & & 35,562 & & & & \\
\hline C_05_A & 85.9 & \multirow{2}{*}{80.90} & 28,538 & \multirow{2}{*}{24,412} & \multirow{2}{*}{13,163} & \multirow{2}{*}{15,527} & \multirow{2}{*}{2593} \\
\hline C_05_B & 75.9 & & 20,286 & & & & \\
\hline C_06_A & 209.4 & \multirow{2}{*}{180.85} & 57,168 & \multirow{2}{*}{50,175} & \multirow{2}{*}{42,869} & & \\
\hline C_06_B & 152.3 & & 43,183 & & & 36,627 & 3943 \\
\hline C_07_A & 119.3 & 11745 & 40,919 & 34863 & 19425 & 32719 & 2730 \\
\hline C_07_B & 115.6 & 117.45 & 28,807 & 34,003 & $19,4 \angle 0$ & 32,119 & 3730 \\
\hline C_08_A & 113.8 & 11290 & 34,521 & 34843 & 23171 & 37084 & 4010 \\
\hline C_08_B & 112.0 & 112.90 & 35,164 & & & & 4010 \\
\hline C_09_A & 139.3 & 14155 & 35,788 & 36.963 & 52,540 & 43,872 & 4347 \\
\hline C_09_B & 143.8 & 141.05 & 38,139 & נo, & & 40,08 & 4347 \\
\hline C_10_A & 137.7 & & 40,605 & 249 & 40088 & 8 & \\
\hline C_10_B & 143.6 & 140.65 & 43,894 & 42,249 & 40,088 & 43,318 & 4297 \\
\hline Average & & & & & 32,121 & 35,383 & 3584 \\
\hline St. dev. & & & & & 11,539 & 9272 & 544 \\
\hline
\end{tabular}

The compressive mean strength and the mean strain recorded at peak stress were of 125.2 MPa and $3143 \mu \mathrm{m} / \mathrm{m}$, respectively. The $f_{c}-\varepsilon$ diagrams (Figure 7) highlighted an expected dispersion of the results due to the anisotropy of material, most likely accentuated by any internal microcracks that the stones of masonry walls may have undergone during the collapse. The Gauss distribution of cylindrical compression strength $(f c)$, elastic secant and dynamic modulus $(E s, E d)$ of each stone specimen were evaluated in Figures 8-10. 


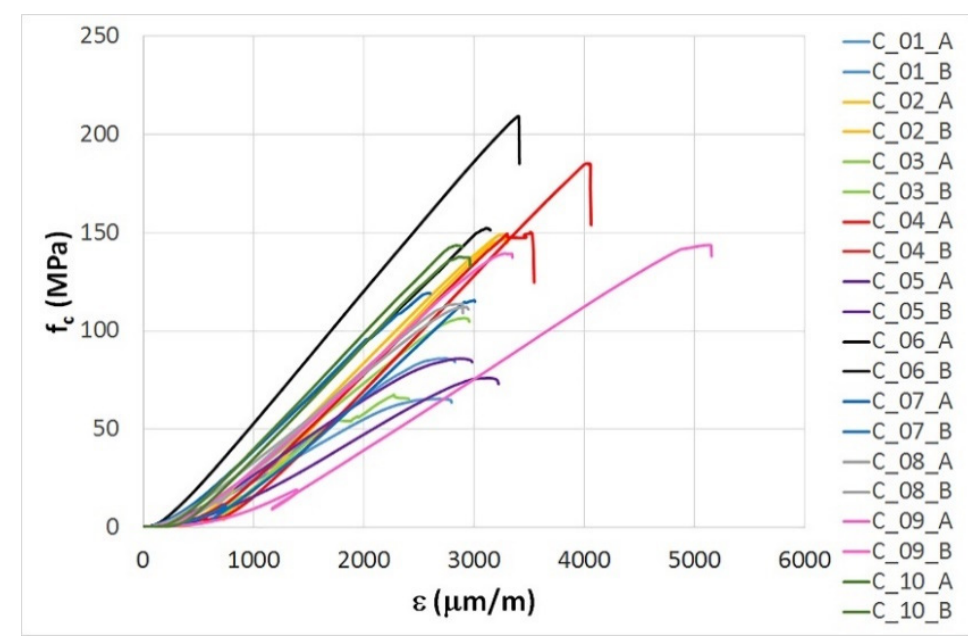

Figure 7. $f_{c}-\varepsilon$ diagrams of compression tests.

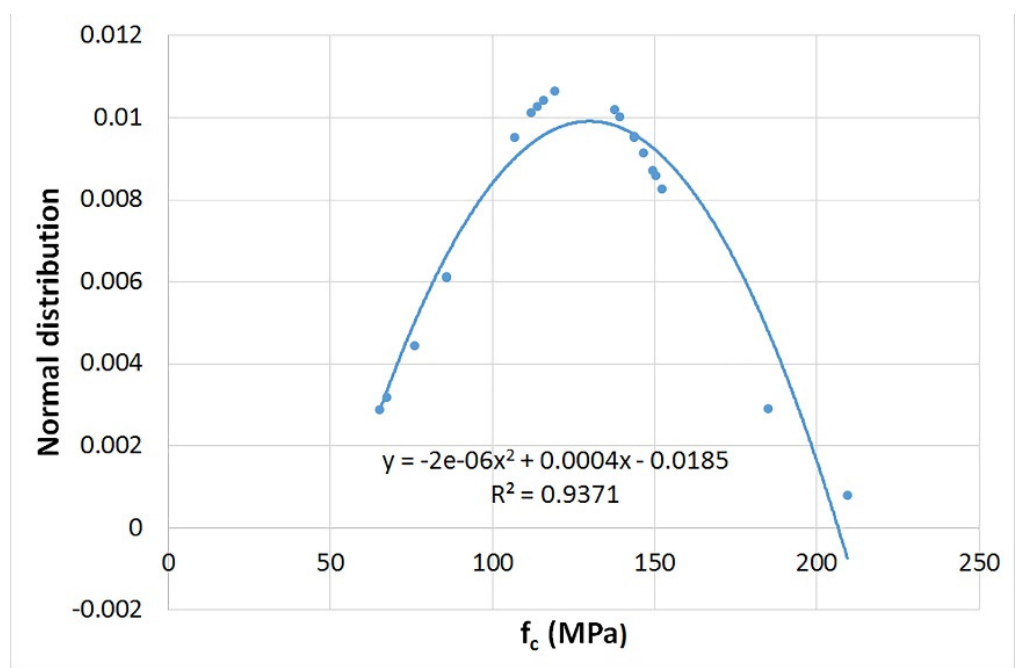

Figure 8. Gauss distribution of cylindrical compression strength of stone cores.

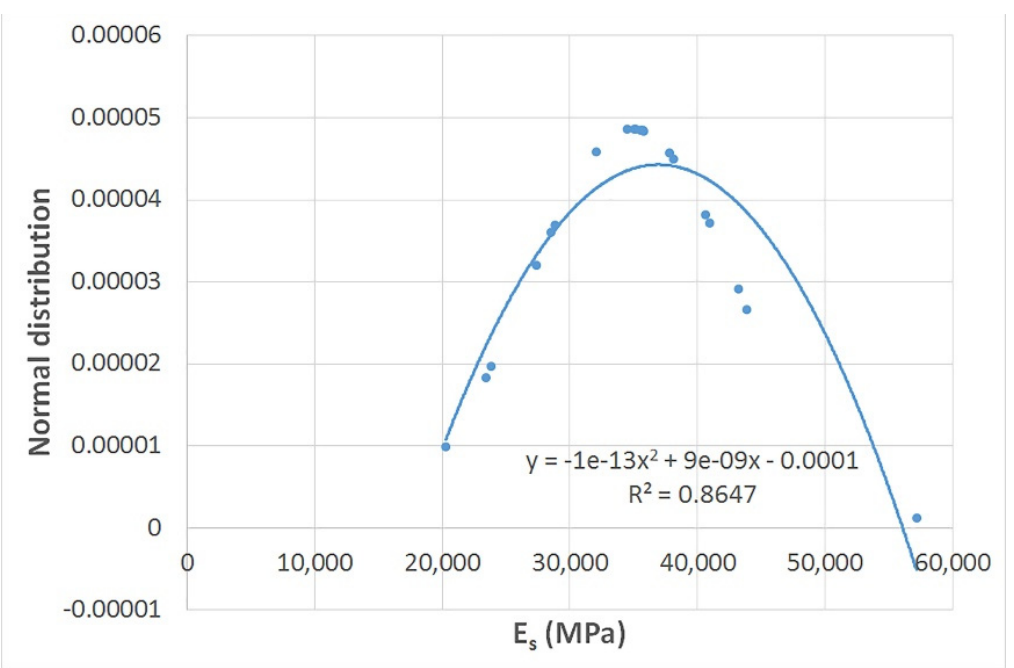

Figure 9. Gauss distribution of elastic secant modulus of stone cores. 


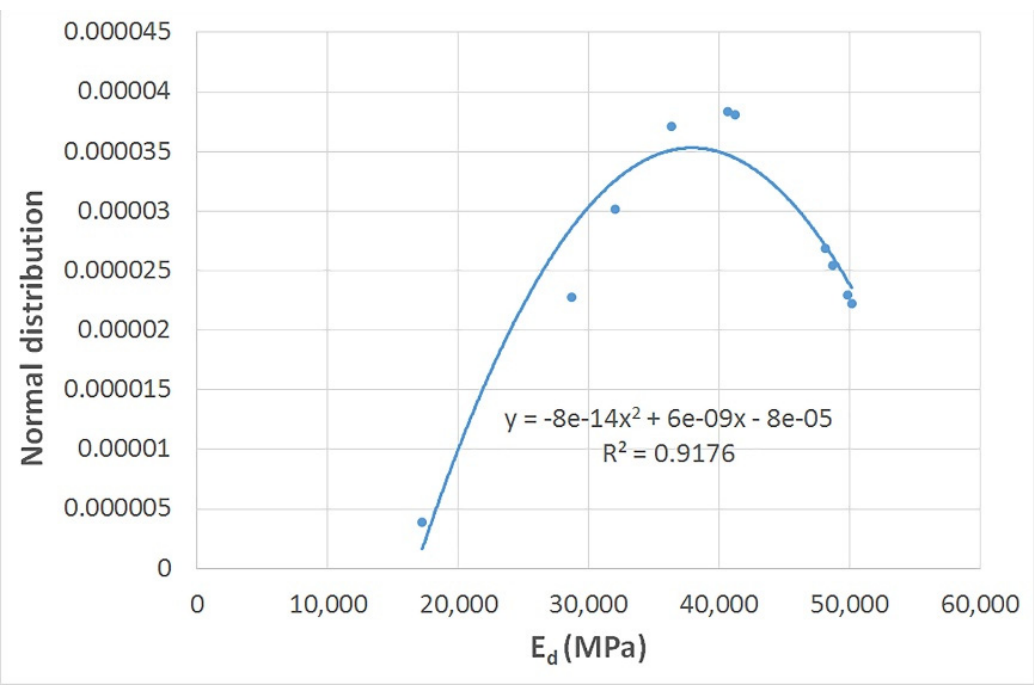

Figure 10. Gauss distribution of elastic dynamic modulus of stones.

In order to validate the potential of non-invasive tests only, in the wake contributions made by other authors [36-38], the following exponential correlation was obtained (Figure 11) between the ultrasonic speed $(v)$, and the cylindrical compression strength $\left(f_{c}\right)$ :

$$
f_{c}=23.131 e^{0.0004 v}
$$

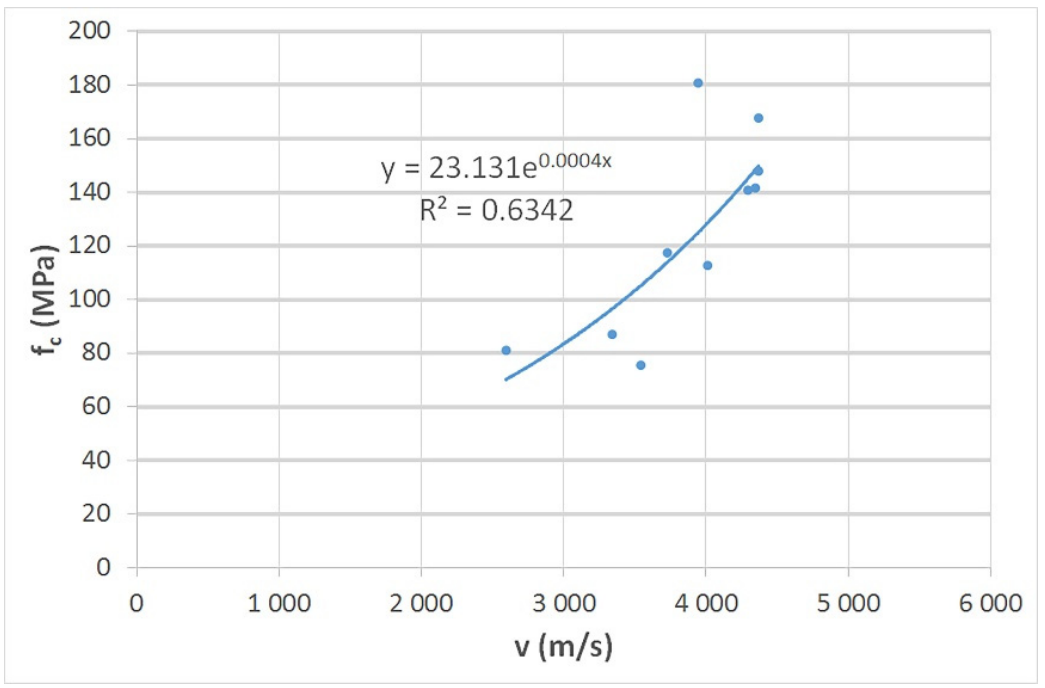

Figure 11. Exponential correlation between cylindric compression strength and ultrasonic speed.

A similar relationship was obtained in Figure 12 by correlating the dynamic elastic modulus $\left(E_{d}\right)$ (from the ultrasonic speed) and the cylindrical compression strength $\left(f_{c}\right)$. Finally, to better characterize the mechanical behavior of sandstone, the values of the static $\left(E_{s}\right)$ and dynamic $\left(E_{d}\right)$ elastic modules were correlated in Figure 13. 


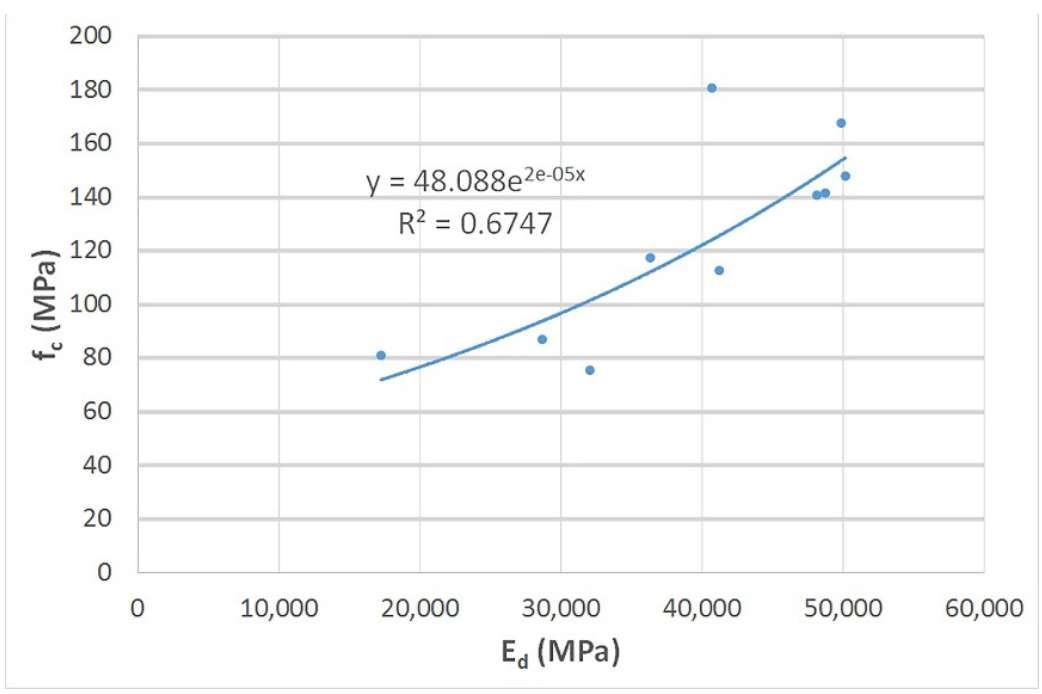

Figure 12. Exponential correlation between cylindric compression strength and dynamic elastic modulus.

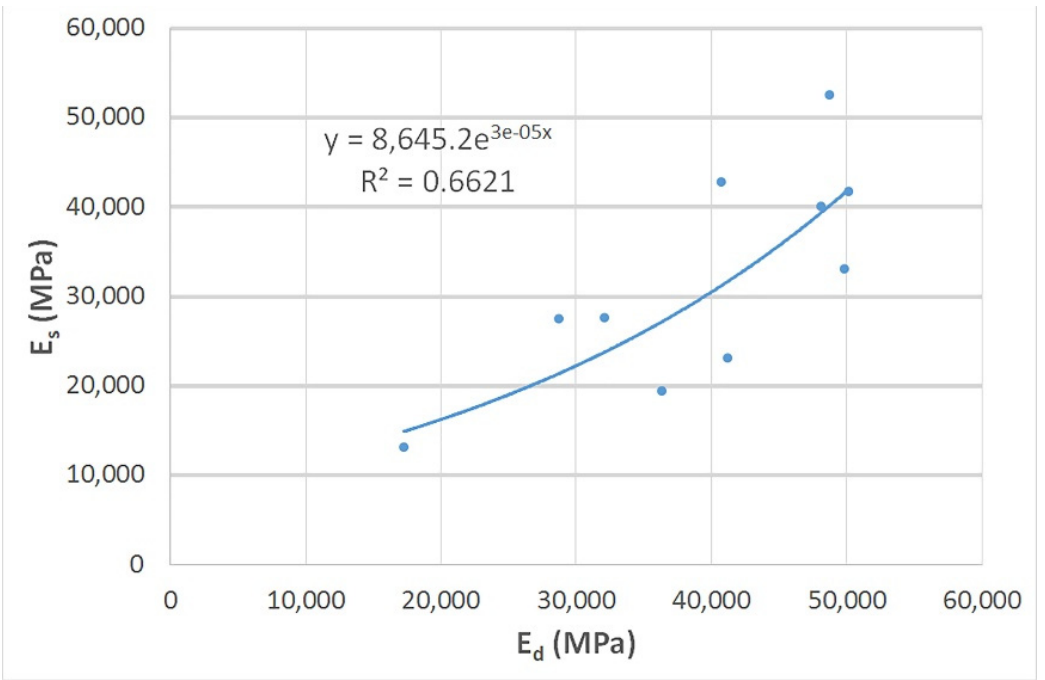

Figure 13. Exponential correlation between dynamic and static elastic modulus.

Regarding the impact test, 15 strokes were performed on each stone taken from the ruins of the St. Agostino church. Figure 14a showed, as an example, the time-force diagram of an impact test (stone n. 4). To fall within a range of greater stabilization of the material, the value of the elastic modulus $\left(E_{s}\right)$ was obtained only between the tenth and the fifteenth beat that recorded $e>0.90$, which was considered more stable (Figure 14b) [31]. 


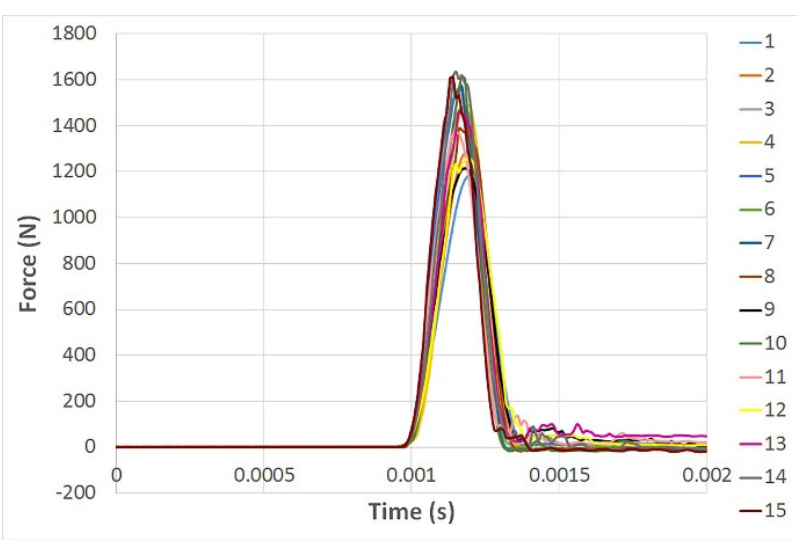

(a)

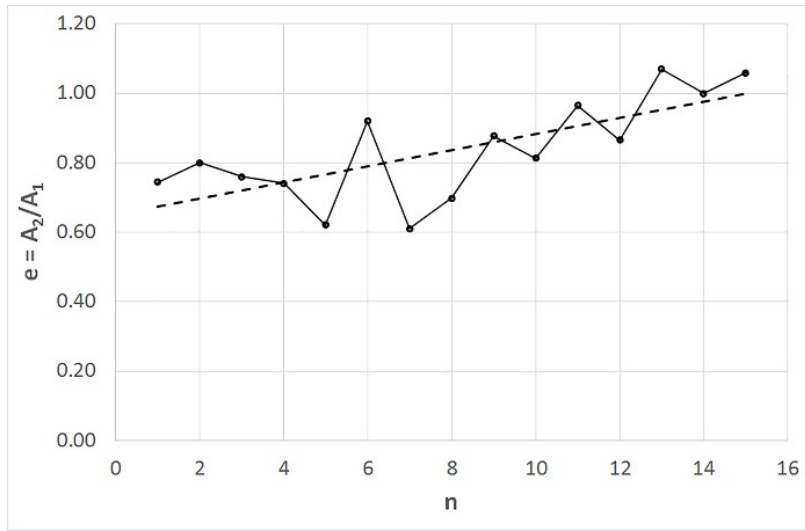

(b)

Figure 14. Impact test on stone n. 4: (a) time-force diagram of the 15 beats; (b) trend of the restitution coefficient (e) vs. number of beats $(n)$.

\section{Discussion}

The experimental campaign involved the calibration and the combination of various in situ non-destructive investigation techniques through laboratory tests on stone samples. A variant of the Sonreb method was tested in the specific case study of the stone walls of the church of St. Agostino in Amatrice, damaged by the 2016 Central Italy earthquake. More specifically, within the Sonreb protocol, the sclerometric test was replaced with the impact test, which highlighted the accuracy of the ultrasonic test to evaluate the elastic modulus of the stone. In this way, it was possible to obtain useful correlations to acquire reliable values of the stones' compression strengths and elastic modulus only by means of in situ non-invasive techniques. The results showed the values with an expected dispersion. The authors evaluated this dispersion as physiological in the case of stone materials, and this was confirmed in other research studies that are present in the scientific literature [36-39] including ongoing experimental studies that demonstrate the anisotropic behavior of the stones relative to the different layers. Furthermore, in this specific case, it is also necessary to consider the presence of microcracks inside the stones, generated by the fall during the seismic actions.

The speed detected by the ultrasonic technique showed a good correlation with the cylindrical compression strength of the same stones (Figure 11). Furthermore, the impact test showed a good precision to estimate the value of the static elastic modulus (Table 1). Even for stones, there was a minimal difference between the dynamic elastic modulus ( $E_{d}$, obtained from ultrasonic tests) and the static one $\left(E_{s}\right.$, obtained by compression tests or by impact tests). According to the scientific literature [38], these differences are variable due the anisotropy that characterizes the sandstone. Even in this specific case study, $E_{d}$ was $10-15 \%$ higher than $E_{s}$, thus validating the results found with only non-invasive techniques.

The correlation can also be improved for wall textures different from those of Amatrice through the intensification of the number of tests. However, the results obtained so far in the Amatrice area showed a full correlation in the average values, they are applicable in situ on other similar buildings, and are useful to estimate the residual strengths of other damaged masonry structures. The correlations between non-destructive tests and laboratory tests will be calibrated for the different types of historic masonry walls. The results of this experimental research may also be useful for further specific shear tests between strengthening mortars and stone structures [40], in order to model the behavior of the mortar-stone composite system, as already carried out in other research studies [41,42], and to validate the mechanical compatibility and durability of strengthening materials to be applied on damaged masonry structures. 


\section{Conclusions}

The experimental research validated a rapid technique, based on non-destructive techniques, to estimate the compression strength and the elastic modulus of the stones that characterize the wall textures of the buildings damaged in the area of Central Italy during the 2016 earthquake. From the St. Agostino church in Amatrice, a well-known building that symbolizes the damage caused by the 2016 Central Italy earthquake, some sandstones were taken and tested in the laboratory under compression test and by ultrasonic and impact tests. The average compression strength of Amatrice sandstone was found of about 125.2 MPa. Moreover, the experimental methodology made it possible to compare the average value of the static elastic modulus obtained from the compression tests (34894 MPa) with the average one estimated from the impact tests (32121 MPa). Very similar values were obtained from the experimental results.

Subsequently, from these tests, it was possible to elaborate a series of correlations between the compression strengths, obtained from the laboratory test, and the values offered by the non-invasive tests. In particular, the applied Sonreb methodology replaced the sclerometric test obtained with the impact hammer, which accurately estimated the value of the elastic modulus in relation to what is already possible with the ultrasonic test. In fact, this experimental research validated the possibility of replacing the Schmidt hammer with the impact test, which offers more information related to the dissipated energy.

The results of this research tend to prove that the obtained experimental results can be applied in situ for a quick and non-destructive estimate of the residual strengths and mechanical characteristics of stones, or other damaged masonry structures with similar texture. For different textures, this estimate can be achieved after specific calibration with limited sampling of cores and laboratory compression tests. The described methodology may have useful applications in the evaluation of the mechanical characteristics of masonry damaged by earthquakes and in the design of safety and strengthening works.

Author Contributions: Conceptualization, A.G. and G.L.; Tests, A.G.; Writing, A.G.; Supervision, G.L.; Project administration, A.G. Both authors have read and agreed to the published version of the manuscript.

Funding: This research received no external funding.

Institutional Review Board Statement: Not applicable.

Informed Consent Statement: Not applicable.

Data Availability Statement: Not applicable.

Acknowledgments: The author greatly thanks the Superintendence Archeology and Fine Arts Landscape of Rieti, the Special Superintendent Office for the areas affected by the earthquake of 24 August 2016, and the Curia of Rieti for providing the opportunity to take the stones and carry out the scientific research. The authors would like to thank Antonino Quattrone, Giovanni Bricca and Franco Grindatto for their valuable technical support during the execution of the laboratory tests.

Conflicts of Interest: The authors declare no conflict of interest.

\section{References}

1. Binda, L.; Gambarotta, L.; Lagomarsino, S.; Modena, C. A multilevel approach to the damage assessment and the seismic improvement of masonry buildings in Italy. In Seismic Damage to Masonry Buildings; Bernardini, A., Ed.; Balkema: Rotterdam, The Netherlands, 1999; pp. 179-194.

2. Castori, G.; Borri, A.; De Maria, A.; Corradi, M.; Sisti, R. Seismic vulnerability assessment of a monumental masonry building. Eng. Struct. 2017, 136, 454-465. [CrossRef]

3. Rovero, L.; Alecci, V.; Mechelli, J.; Tonietti, U.; De Stefano, M. Masonry walls with irregular texture of L'Aquila (Italy) seismic area: Validation of a method for the evaluation of masonry quality. Mater. Struct. 2016, 49, 2297-2314. [CrossRef]

4. Sorrentino, L.; da Porto, F.; Magenes, G.; Penna, A. Seismic behaviour of ordinary masonry buildings during the 2016 central Italy earthquakes. Bull. Earthq. Eng. 2019, 17, 5583-5607. [CrossRef]

5. Borri, A.; Corradi, M. Architectural Heritage: A Discussion on Conservation and Safety. Heritage 2019, 2, 41. [CrossRef] 
6. Sisti, R.; Di Ludovico, M.; Borri, A.; Prota, A. Damage assessment and the effectiveness of prevention: The response in buildings in Norcia. Bull. Earthq. Eng. 2019, 17, 5393-5397. [CrossRef]

7. Spyrakos, C.C.; Maniatakis, C. Seismic protection of monuments and historic structures-The seismo research project. In Proceedings of the VII European Congress on Computational Methods in Applied Sciences and Engineering (ECCOMAS Congress 2016), Crete Island, Greece, 5-10 June 2016.

8. Lagomarsino, S.; Podestà, S. Seismic vulnerability of ancient churches: Damage assessment and emergency planning. Earthq. Spectra 2004, 20, 377-394. [CrossRef]

9. Grazzini, A.; Chiabrando, F.; Foti, S.; Sammartano, G.; Spanò, A. A Multidisciplinary Study on the Seismic Vulnerability of St. Agostino Church in Amatrice following the 2016 Seismic Sequence. Int. J. Herit. Archit. 2020, 14, 885-902. [CrossRef]

10. Parisi, F.; Lignola, G.P.; Augenti, N.; Prota, A.; Manfredi, G. Rocking response assessment of in-plane laterally-loaded masonry walls with openings. Eng. Struct. 2013, 56, 1234-1248. [CrossRef]

11. Tomic, I.; Vanin, F.; Božulic, I.; Beyer, K. Numerical Simulation of Unreinforced Masonry Buildings with Timber Diaphragms. Buildings 2021, 11, 205. [CrossRef]

12. Gonen, S.; Pulatsu, B.; Erdogmus, E.; Karaesmen, E.; Karaesmen, E. Quasi-Static Nonlinear Seismic Assessment of a Fourth Century, A.D. Roman Aqueduct in Istanbul, Turkey. Heritage 2021, 4, 25. [CrossRef]

13. Pulatsu, B.; Erdogmus, E.; Lourenço, P.B.; Lemos, J.V.; Tunkay, K. Simulation of the in-plane structural behavior of unreinforced masonry walls and buildings using DEM. Structures 2020, 27, 2274-2287. [CrossRef]

14. Grillanda, N.; Valente, M.; Milani, G.; Chiozzi, A.; Tralli, A. Advanced numerical strategies for seismic assessment of historical masonry aggregates. Eng. Struct. 2020, 212, 110441. [CrossRef]

15. Binda, L.; Cantini, L.; Tedeschi, C. Diagnosis of Historic Masonry Structures Using Non-Destructive Techniques. In Nondestructive Testing of Materials and Structures; Buyukozturk, O., Tasdemir, M.A., Gunes, O., Akkaya, Y., Eds.; Springer: Heidelberg, Germany, 2013; pp. 1089-1102.

16. Verstrynge, E.; Lacidogna, G.; Accornero, F.; Tomor, A. A review on acoustic emission monitoring for damage detection in masonry structures. Constr. Build. Mater. 2020, 268. [CrossRef]

17. Invernizzi, S.; Lacidogna, G.; Lozano-Ramirez, N.; Carpinteri, A. Structural monitoring and assessment of an ancient masonry tower. Eng. Fract. Mech. 2018, 210, 429-443. [CrossRef]

18. Valluzzi, M.R.; Lorenzoni, F.; Deiana, R.; Taffarel, S.; Modena, C. Non-destructive investigations for structural qualification of the Sarno Baths, Pompeii. J. Cult. Herit. 2019, 40, 280-287. [CrossRef]

19. Grazzini, A. Sonic and Impact Test for Structural Assessment of Historical Masonry. Appl. Sci. 2019, 9, 5148. [CrossRef]

20. Vasconcelos, G.; Lourenço, P.B.; Alves, C.S.A.; Pamplona, G. Prediction of the mechanical properties of granites by ultrasonic pulse velocity and schmidt hammer hardness. In Proceedings of the 10th North American Masonry Conference, St. Louis, MO, USA, 3-6 June 2007; Myers, B., Ed.; Masonry Society: Longmont, CO, USA, 2007.

21. Vasanelli, E.; Sileo, M.; Calia, A.; Aiello, M.A. Non-destructive techniques to assess mechanical and physical properties of soft calcarenitic stones. Procedia Chem. 2013, 8, 35-44. [CrossRef]

22. Cobanoglu, I.; Celik, S.B. Estimation of uniaxial compressive strength from point load strength, Schmidt hardness and P-wave velocity. Bull. Eng. Geol. Environ. 2008, 67, 491-498. [CrossRef]

23. Concu, G.; De Nicolo, B.; Valdes, M. Prediction of Building Limestone Physical and Mechanical Properties by Means of Ultrasonic P-Wave Velocity. Sci. World J. 2014, 14, 1-8. [CrossRef]

24. NTC 2018-D.M. 17/01/2018 Norme Tecniche per le Costruzioni; Ministero delle Infrastrutture e dei Trasporti: Rome, Italy, 2018. (In Italian)

25. Monaco, M.; Aurilio, M.; Tafuro, A.; Guadagnuolo, M. Sustainable Mortars for Application in the Cultural Heritage Field. Materials 2021, 14, 598. [CrossRef]

26. UNI EN 1926: 2007. In Metodi di Prova per Pietre Naturali_Determinazione Della Resistenza a Compressione Uniassiale; UNI: Milan, Italy, 2007. (In Italian)

27. ASTM D2845 1995. In Standard Test Method for Laboratory Determination of Pulse Velocities and Ultrasonic Elastic Constants of Rock; ASTM: West Conshohocken, PA, USA, 1995.

28. UNI EN 12504-4: 2005. In Prove sul Calcestruzzo nelle Strutture—Parte 4: Determinazione Della Velocità di Propagazione Degli Impulsi Ultrasonici; UNI: Milan, Italy, 2005. (In Italian)

29. Chen, Y.; Wang, S.; Wang, E. Strength and elastic properties of sandstone under different testing conditions. J. Cent. South Univ. 2007, 14, 210-215. [CrossRef]

30. Xu, H.; Zhou, W.; Xie, R.; Da, L.; Xiao, C.; Shan, Y.; Zhang, H. Characterization of Rock Mechanical Properties Using Lab Tests and Numerical Interpretation Model of Well Logs. Math. Probl. Eng. 2016, 2016. [CrossRef]

31. Grazzini, A. In Situ Analysis of Plaster Detachment by Impact Tests. Appl. Sci. 2019, 9, 258. [CrossRef]

32. Bocca, P.; Scavia, C. The impulse method for the evaluation of concrete elastic characteristics. In Proceedings of the 9th International Conference on Experimental Mechanics, Copenhagen, Denmark, 20-24 August 1990.

33. Grazzini, A.; Fasana, S.; Zerbinatti, M.; Lacidogna, G. Non-Destructive Tests for Damage Evaluation of Stone Columns: The Case Study of Sacro Monte in Ghiffa (Italy). Appl. Sci. 2020, 10, 2673. [CrossRef]

34. Johnson, K.L. Contact Mechanics; Cambridge University Press: Cambridge, UK, 1985.

35. Deresiewicz, H. A note on Hertz Impact. Acta Mech. 1968, 6, 110-112. [CrossRef] 
36. Aliabdo, A.A.E.; Elmoaty, A.E.M.A. Reliability of using nondestructive tests to estimate compressive strength of building stones and bricks. Alex. Eng. J. 2012, 51, 193-203. [CrossRef]

37. Presa, L.; Costafreda, J.L.; Martín, D.A. Correlation between Uniaxial Compression Test and Ultrasonic Pulse Rate in Cement with Different Pozzolani Additions. Appl. Sci. 2021, 11, 3747. [CrossRef]

38. Dhawan, K.R.; Muralidhar, B. Relationship between static and two types of dynamic moduli for different rocks. Indian Geotech. J. 2015, 45, 341-348. [CrossRef]

39. Jurowski, K.; Grzeszczyk, S. Influence of Selected Factors on the Relationship between the Dynamic Elastic Modulus and Compressive Strength of Concrete. Materials 2018, 11, 477. [CrossRef]

40. Bocca, P.; Grazzini, A.; Masera, D. Fatigue behaviour analysis for the durability prequalification of strengthening mortars. J. Phys. Conf. Ser. 2011, 305, 012041. [CrossRef]

41. Grazzini, A.; Lacidogna, G.; Valente, S.; Accornero, F. Delamination of plasters applied to historical masonry walls: Analysis by acoustic emission technique and numerical model. IOP Conf. Ser. Mater. Sci. Eng. 2018, 372, 012022. [CrossRef]

42. Grazzini, A.; Lacidogna, G.; Valente, S.; Accornero, F. Acoustic emission and numerical analysis of the delamination process in repair plasters applied to historical walls. Constr. Build. Mater. 2020, 236, 117798. [CrossRef] 